\title{
Solutions for Improving Living Standards in Rural Areas from Romania
}

\author{
Marinela Ilie \\ PhD Student, Bucharest University of Economic Studies, 6 Piata Romana, Bucharest, Romania \\ e-mail: Marinela.ilie93@gmail.com
}

DOI: 10.51865/EITC.2021.03.04

\begin{abstract}
Rural areas play an important socio-economic role in Romania, as they cover $87.1 \%$ of the territory, $46 \%$ of the population in 2012, produce 32\% of gross value added and the employed population in rural areas represents $45.2 \%$ of the total population. Independent and family activities play an important role in rural Romania, and agriculture is the sector that covers much of this trend. The purpose of this paper is to highlight the main present needs of the rural areas in Romania but also the measures that must be taken to meet these needs.
\end{abstract}

Keywords: rural; development; living standards; Romania.

JEL Classification: $Q 01 ; Q 1 ; Q 56 ; Q 16$.

\section{Introduction}

Most rural people have a low level of education and therefore earn less than employees in other sectors. Hourly labor productivity in agriculture, forestry and fishing recorded values of 1.2 EURO(EUR) / hour in 2010 and 2 EURO / hour in 2012, compared to most other activities (industry, construction, etc.) where it exceeds $10 \mathrm{EURO/hour.} \mathrm{Low} \mathrm{wages} \mathrm{and} \mathrm{low} \mathrm{employment}$ opportunities have created stable patterns of poverty in rural areas. According to National Institute of Statistics (INS) data, the unemployment rate in rural areas was 5\% in 2012 compared to $8.3 \%$ in urban areas; at the level of 2012, self-employed and unpaid family workers in rural areas accounted for $88 \%$ of the total employed population employed by this professional status and $61.4 \%$ of the total employed rural population in 2012. Poverty is three times more prevalent in rural areas than in urban areas. In 2012, while only 11 percent of people living in urban areas were at risk of poverty, $38 \%$ of those living in rural areas were at risk.

This difference can be easily explained by the structural characteristics of a typical rural locality, with an aging population, which has only a few sources of income. As a result of declining employment opportunities, a process of net emigration has begun, led by the younger generation. It is estimated that approximately 1.5 million people ( $7 \%$ of the population) work abroad. At the same time, remittances play an increasingly important role in the incomes of rural households in Romania, providing $2 \%$ of The Gross Domestic Product (GDP). The current state of physical infrastructure hinders the development of rural areas in Romania. The road 
network, water supply and sewerage services are in great need of repairs and expansion. Some rural schools are still in a precarious situation, which contributes to the low level of education in these areas.

To combat the problems presented above, appears the document entitled: Strategy for the Development of the Medium and long-term agri-food sector 2020-2030 issued by the Ministry of Agriculture and Rural Development (MADR). Based on this, in this paper are presented and reinterpreted the measures and objectives that must be the basis for improving living standards in rural areas of Romania, so the question of research is: "What are the solutions which can be implemented to improve living standards in rural areas from Romania?".

\section{Literature Review}

Rural development is very important and often very difficult to understand. Although it seems to be a new concept, it has had an award in the literature since the 1980s. It could be defined as a way of maintaining the rural areas by diversifying the rural economy, which will lead to the improvement of life quality in the rural area. The concept of EU agricultural policy has been mentioned since 1957, under the Treaty of Rome. In 1962, the Common Agricultural Policy (CAP) of the European Union entered into a form. Rural development policy is currently the second pillar of the CAP, and is currently playing a very important role in solving the problems that the 21 st century faces. Strengthening rural development policy is a priority of the EU, as it aims to stimulate job creation and to improve the quality of life in rural areas. Sustainable development of agriculture is a wide debated issue and is the subject of numerous development strategies at national, European and global level, being an integrated process.

Often under the impact of old production systems, characterized by the accelerated and irrational development of the industry, the rural area has undergone some transformations in economic, social and ecological conditions that most often resulted in exodus and impoverishment of the rural population. Given this situation, the efforts are truly remarkable submitted by developed countries, and not only, in order to balance the village-city relationship, reconciliation and the revitalization of the rural space, which is the keeper of unique material and spiritual values. According to Commission of the European Communities, 2019, the rural area is an extremely varied area, the agricultural area, the area occupied by forests and pastures, non-agricultural rural area and rural agglomerations are an entity distinct from the urban space which is characterized by a strong concentration of demographic vertical and horizontal structures. In order to identify and enhance the rural area, according to its elements, a number of features must be taken into account. The peculiarities of the rural space, regarded as physical and social space, are multiple and not at all easy to order by value. In this sense, any attempt to identify the characteristics of the rural space, to synthesize and highlight rural space is not enough. Compared to the urban space, the rural space presents a series of particularities that give it individuality, specificity and authenticity. The following characteristics of the rural space can be highlighted:

o agriculture together with related activities is the one that dominates in the structure of economic development in rural areas;

o the active population of the rural area is mainly active in the primary sector of economy and is characterized by pluriactivity, which determines the polycalification professional;

o private family property predominates in the rural area, this imprinting a certain mood of the rural population;

o in rural areas the degree of social cohesion is higher, the inhabitants are interested in community problems and participate in solving them without any pretensions financial;

o the population density is low, the space is more airy and less stressful; 
o in rural areas, life is based on a series of norms emanating from multi secular life, from local traditions, customs and culture.

The main functions to be performed by the rural area are: the function of supply, relaxation and balance. These can only be met if it remains an attractive and original living environment, with good infrastructure, agriculture and forestry viable, providing favorable conditions for nonagricultural economic activities. In this sense the space of rural areas must simultaneously fulfill three major functions: economic, ecological and sociocultural (Ilie, 2019).

Component of the economic and social strategy of sustainable development, rural development is a management problem that involves knowledge down to the smallest detail of the realities of rural communities and whose monitoring should not be neglected by specialists.

The notion of rural development encompasses all actions aimed at improving the quality of life of the rural population, with special care in terms of conservation of natural and cultural landscape and ensuring the sustainable development of rural areas in accordance with the conditions and specifics of the targeted space.

The current philosophy of rural space development focuses on the concept of sustainable development, which involves ensuring the balance between the conservation of economic, social, rural ecological space and tendency to modernize environment areas. On the other hand, there is a tendency to conserve the current values and characteristics of the rural area. Sustainable agriculture aims to manage resources to meet present and future needs, while maintaining and improving the environment and protecting natural resources.

The policy of sustainable development aims to achieve an improvement in the quality of life of citizens, which implies economic progress. Sustainable development takes into account three important dimensions, namely the economic, social and ecological dimension.

The rural area occupies an important place in the history, civilization and national identity of the European countries. From these considerations derives the important role played by rural development policies in European policies (Warren, Brokensha, Slikkerveer, 2013). Europe's future depends largely on the potential for sustainable development of the area. Romania is one of the least urbanized countries in the EU as presented in Figure 1. According to the data below, $45.5 \%$ of the population is located in predominantly rural areas, $43.9 \%$ in intermediate areas, while only $10.6 \%$ live in predominantly urban areas. This is one of the highest levels of the rural population in the Network Management System (NMS). Between the European states, the United Kingdom (only $3 \%$ ) is the most urbanized.

The share of agriculture, forestry and fisheries in Gross Value Added (GVA) reflects the high dependence on the agricultural sector and shows the need to implement policies dedicated to rural income diversification (Figure 1). Until now, the capacity of Romanian farms to undertake other lucrative activities has been extremely limited and among the lowest in the EU. In 2010, only $1 \%$ of the 3.8 million farms in Romania reported other lucrative activities, compared to $5 \%$ in the EU. In some of the most developed old Member States, the percentage is almost $52 \%$ (Denmark), 37\% (Austria) and 31\% (Germany) in terms of income from non-agricultural activities. Also, of the 42,750 farms in Romania which diversified their incomes, only $11 \%$ generated more than $50 \%$ of their profit from non-agricultural activities. Again, this contrasts significantly with the EU-27 average where $30 \%$ of farms with other gainful activities are able to generate more than half of the income from other non-agricultural activities. 


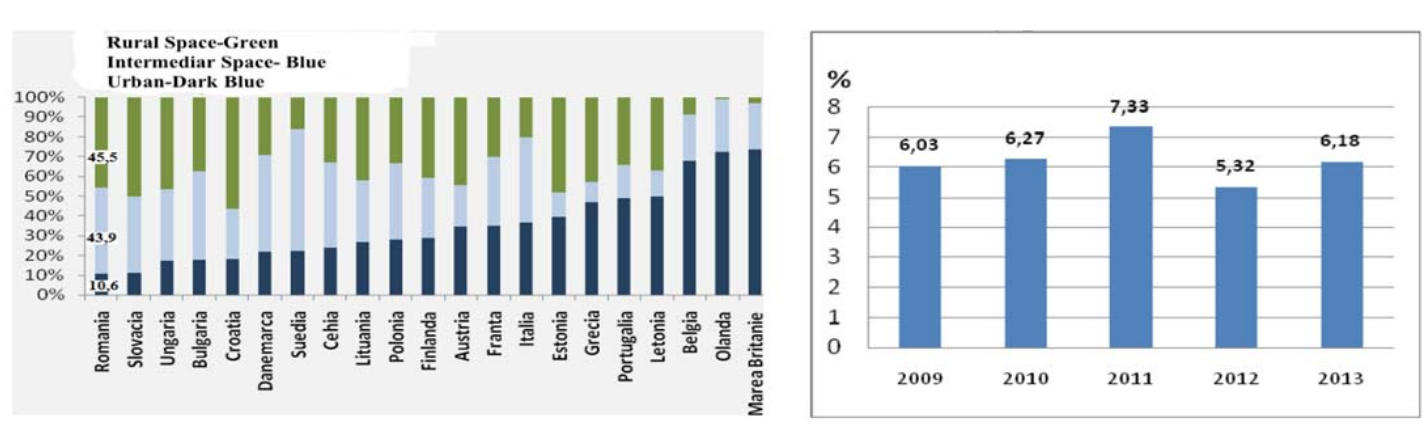

Fig. 1. Distribution of the population by degrees of urbanization in several EU countries and share of agriculture, forestry and fishing in Gross Value Added-GVA

Source: INS, Distribution of population in European countries in 2014, posted in 2015.

Romania has a relatively low percentage of people living in households with a very low labor intensity. Only 7.4\% of Romania's population under the age of 60 fell into this category in 2012 (the EU average was $10.4 \%$ ). Rural areas are facing a significant population decline, in the context of a decrease in the total population. Fifty years ago, two thirds of Romania's population lived in villages, while in 2009-2012 the number of villagers decreased to $46 \%$ of the total, a percentage that remained in the 4 years (Figure 2). After the maximum in 1990 (23.2 million), Romania's population decreased, reaching 20 million inhabitants in 2012. The rural population decreased from 10.6 million in 1990 to 9.2 million in 2012.

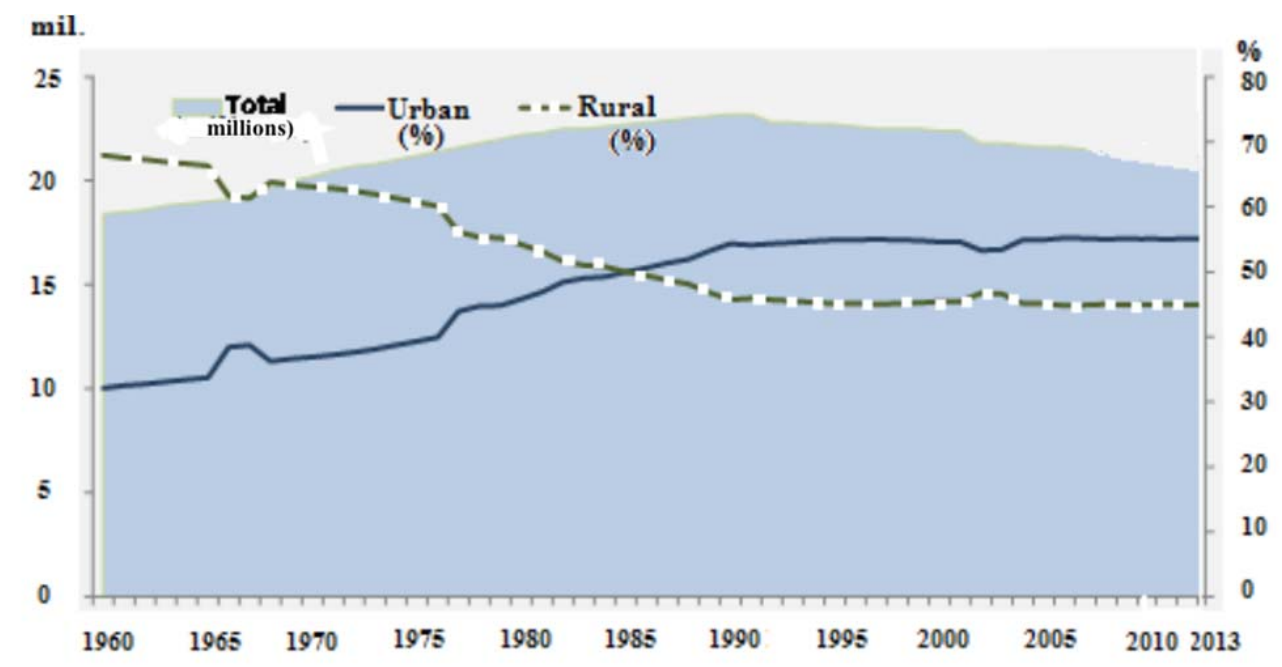

Fig. 2. The population of Romania, in total and by areas, 1960-2013

Source: Eurostat- Statistical data on the structure of agricultural holdings, Version 3 May 2019.

The aging rate, negative growth and increased external migration in recent years are the main factors responsible for the decline of the rural population, despite a positive internal migration to rural areas. In 2011, from the total natural decrease of the population, $57 \%$ was represented by the decrease of the rural population and the increase of the population over 65 years old and the decrease of the population under 14 years of age accelerated this process. Although positive, internal migration from urban to rural areas cannot compensate for the decline of the rural population. The discrepancies between the city and the village are significant both in terms of income and living conditions, measured in terms of access to infrastructure and basic services. Given that there is much regional and territorial specificity in terms of needs, challenges and opportunities, public policies must allow for the adaptation of development strategies in which local action groups (LAGs) take the lead. According to INS, in 2013, the average of total income represented, in nominal terms, 2559.05 RON (Romania's National Currency, 1EURO = 
4,90 RON) per month / household. In the farmer's household, the income was $2098.1 \mathrm{RON}$ per month, compared to the income per employee's household of 3419.13 RON per month. For the same year, the average of total expenses represented, in nominal terms, $2317.40 \mathrm{RON}$ per month / household. In the farmer's household, the expenses were 2038.26 RON per month, compared to the expenses on the employee's household of 3039.17 RON per month. The difference between income and expenses is about $380 \mathrm{RON} /$ household of employees compared to only 60 $\mathrm{RON}$ / household of a farmer.

\section{Case Study}

As presented in Table 1, the impact indicators of sustainable development for Romania were not the same as the EU' targets. Improving living standards in rural areas by ensuring infrastructure and basic services like those in urban areas will reduce the differences in rural incomes between Romania and the EU average.

Table 1. Impact indicators

\begin{tabular}{|l|l|l|l|}
\hline \multicolumn{1}{|c|}{ Road sign } & \multicolumn{1}{|c|}{ Current level } & \multicolumn{1}{c|}{ Target 2020 } & Target 2030 \\
\hline $\begin{array}{l}\text { Differences between } \\
\text { rural incomes in } \\
\text { Romania and the EU } \\
\text { average }\end{array}$ & $\begin{array}{l}\text { 16.6\% of the EU average } \\
\text { in predominantly rural } \\
\text { areas (2009) }\end{array}$ & $\begin{array}{l}\text { 25\% of the EU average in } \\
\text { predominantly rural areas }\end{array}$ & $\begin{array}{l}\text { 50\% of the EU } \\
\text { average in } \\
\text { predominantly } \\
\text { rural areas }\end{array}$ \\
\hline $\begin{array}{l}\text { Rural population access } \\
\text { to basic services } / \\
\text { infrastructure }\end{array}$ & $\begin{array}{l}50-60 \% \text { of rural } \\
\text { households }\end{array}$ & $\begin{array}{l}\text { At least } 65 \% \text { of urban } \\
\text { access levels }\end{array}$ & $\begin{array}{l}\text { At least } 80 \% \text { of } \\
\text { urban access } \\
\text { levels }\end{array}$ \\
\hline
\end{tabular}

Source: Author processing from Romania's National Development Strategy.

The future well-being of the rural population in Romania depends on the active integration of the citizens in a prosperous and increasingly diversified rural economy and to be supported by infrastructure and services that respect the principles of a clean environment. The discrepancies between the city and the village are significant both in terms of income and living conditions, measured in terms of access to infrastructure and basic services. Although investments in infrastructure have increased systematically, rural physical infrastructure lags behind urban infrastructure. In the period 2000-2009 the investments in roads, streets and access roads increased tenfold, two fifths of the rural population and over a quarter of the communes still have access problems (seasonal or permanent) to the main road network.

Less than $50 \%$ of rural households are connected to, and systematically use, a sewerage system and only two thirds of rural households use a water supply network. The small number of health units, the lack of qualified medical staff in the remaining units and the poorly endowed schools in the rural area complete the image of an area facing various demographic challenges, as regional disparities. The current situation has a serious impact on the quality of life of the entire rural population and especially of young people and the elderly and vulnerable. Faced with an aging and declining population, rural areas need coherent and sustained investment in infrastructure and services.

The measures from National Plan for Rural Sustainable Development (PNDR), in the rural localities will support the establishment, extension and modernization of the road infrastructure of local interest (communal roads, neighboring roads, streets inside the localities), of the water / wastewater infrastructure (public water / wastewater network from rural localities) as well as educational and social services regarding the establishment / modernization of nurseries, kindergartens, modernization of schools, school structures after school and will be supported the 
conservation of cultural heritage (monastic settlements, cultural centers). These investments will help increase the attractiveness of rural areas, especially for young and educated people, who currently account for almost half of rural employees.

The exodus of young and educated people from rural areas will jeopardize the success of all other public policy interventions, along with economic stability and the sustainability of rural areas. A rural area becomes prosperous by motivating its active population, determined by the level and stability of its income and its ability to support its family. However, agriculture provides less than $10 \%$ of permanent employees. Diversification and income growth are linked to long-term employment opportunities, employment in sectors other than agriculture and social involvement, all of which are linked to the sustainable development of the rural business sector. It is necessary to support the development of rural entrepreneurship. These will generate employment through the establishment and development of rural businesses. By ensuring the transformation and processing of the agricultural product for food recovery potential in Romania, a high mandatory measure to improve the living standards of rural areas is represented by the development of rural tourism and agrotourism based on specific, traditional and regional products. This would increase employment / income opportunities and reduce the gap between rural and urban incomes. Such an intervention will have a positive impact on the active population, which will no longer be dependent on subsistence agriculture, offering new and stable income prospects.

Because of the poverty level in rural areas, there are many subsistence farmers which make this area socio-economically vulnerable. The level of income in Romania is far behind the EU-27 average, rural areas being the most affected. The diversification of incomes in fields other than agricultural production has so far remained low in Romania. This problem can be solved by authorities who must support the diversification of agricultural incomes by creating occupational alternatives (other productive activities) to the inhabitants of the rural area. The agri-food processing sector and the agricultural services sector offer jobs and increased income opportunities. Investments are needed (mainly through PNDR and the private sector) to stimulate rural entrepreneurship to generate income from agricultural processing, agricultural services, traditional crafts, rural tourism and ecotourism, wood processing, industrial production and services.

On average, in the period 2008-2010, the GDP per capital generated by the predominantly rural regions of Romania represented only $16.6 \%$ of the EU-27 average (Figure 2). Only Bulgaria, with $12.8 \%$, ranked lower. However, the income gap in Romania and the EU-27 for predominantly urban regions is only $44.7 \%$. The years of accession and post-accession coincided with the beginning of a trend of significant convergence towards the EU average for all three types of regions. This positive development was overshadowed, to some extent, by the onset of the economic crisis in 2008/2009. Despite rising incomes, rural areas appear to be slower than urban areas in recovering.

The agri-food processing sector and the agricultural services sector offer jobs and increased income opportunities. Rural tourism, as an alternative source of income, creates special opportunities, especially in mountainous areas and in the Danube Delta. The development of rural tourism can be an option for rural households to obtain additional income. The number of tourists in agrotourism pensions from 2008 to 2013 increased by $40 \%$. However, only $7.5 \%$ of tourists who visited agrotourism destinations were foreigners in 2013, although in the case of hotels and motels, the percentage was $25 \%$. Support will materialize mainly through the development of small-scale non-agricultural businesses. Currently, most non-agricultural activities in rural areas are carried out by micro-enterprises (Ilie, 2019).

Deficient state of physical infrastructure is one of the most important factors, which limits the possibilities of rural development in Romania. Only half of the communes have direct access to 
the road network, which means that the current road network serves only $3 / 5$ of the entire rural population. Existing physical infrastructure needs repair or needs to be rebuilt.

Investments in the construction, modernization and renovation of rural physical infrastructure roads, water and sewerage, will develop a modern rural infrastructure and quality rural services. These are the prerequisites for the sustainable growth of the rural economy and the improvement of the quality of life for rural areas. Successful and timely development of physical infrastructure is crucial for the future as it provides the basis for jobs and access to resources and institutions. Such investments have beneficial effects on the labor market in rural areas, by providing jobs in the infrastructure construction sector in rural areas.

The involvement of the local community in the development of the rural space is limited, the initiatives of the local community have started recently and are still weak and the capacity of the local public administration needs improvement. The opportunities, conditions and needs of rural development vary greatly from one region to another. Development must be adapted accordingly, in close cooperation with local authorities. There is no single model for managing rural development, just as there is no single determinant of a region's economic trajectory. Therefore, rural policies are needed to increase local capacity and stakeholder participation, to mobilize initial resources and to address external forces, best responding to local needs.

The Local Development Strategies (SDL) aims to select a coherent set of measures adapted to the specific priorities of the territory and to capitalize on the authentic local potential of the territory. The Program Links Between Actions for the Development of the Rural Economy (LEADER) will contribute to the development of rural areas, including small towns with a maximum population of 20.000 and will facilitate the implementation of projects with an innovative multisectoral and cross-cutting approach supporting the needs of the population in LEADER eligible territory.

Promoting the concept of development partnership by supporting local rural community initiatives is very important for the well-being of rural areas from Romania. In order to activate the endogenous development potential, support and incentives need to be directed to community representatives. Support is needed to allow locals to express their choice in how they want to develop their own living conditions. Increasing the attractiveness of rural areas is important, as it contributes to strengthening social and cultural ties at the local level. The initiatives of local communities in rural areas and the promotion of the concept of partnership in development will be further supported by PNDR.

According to World Commission on Environment and Development, 2017, in response to the challenges of the new context, the 2020 Common Agricultural Policy (CAP) has embarked on a process of transformation, taking on strong obligations to address food security, sustainable natural resource management and balanced territorial development. Public and private actors will act in concert to counter the threats identified at global and European level as well as to seize new opportunities. The EU has presented an ambitious Europe 2020 strategy, which supports smart, sustainable and inclusive growth. The Europe 2020 strategy sets the tone and objectives to which all national and sectorial strategies must respond in order to stimulate the EU's potential for sustainable growth and competitiveness. In this context, Romania, through this strategy, defines a series of strategic approaches, regarding the future of agriculture and rural areas, through which its potential will be intelligently exploited, thus reacting, successfully, to the changing global and European environment. 


\section{Conclusions}

In fact, to achieve the EU' targets for 2030 it is very necessary that in rural areas from Romania to be implemented the following measures:

o Modernization and increase of viability of agricultural holdings by consolidating them, opening to the market and processing of agricultural products;

0 Encouraging the rejuvenation of generations of farmers by supporting the establishment of young farmers;

o Development of basic rural infrastructure as a precondition for attracting investments in rural areas and creating new jobs and implicitly for the development of rural areas.

o Encourage the diversification of the rural economy by promoting the creation and development of non-agricultural sectors in rural areas;

o Promoting the fruit sector, as a sector with specific needs, through a dedicated subprogram;

o Encourage local development placed in the responsibility of the community through the LEADER approach. LEADER's cross-cutting competence improves competitiveness, quality of life and diversification of the rural economy, as well as combating poverty and social exclusion.

Until 2030, rural development in Romania aims to achieve the goals of the European Union by ensuring and maintaining a close and beneficial link between agriculture and environment through smart and sustainable use of agricultural land, labor and capital.

The Romanian farmer in the 21st century must be competitive, at the level of other economic activities, reaching the same level of well-being and similar living conditions as the inhabitants of urban areas. Romania will ensure its food security and will become an important player in the European and international agri-food trade. The vision, the strategy for the development of the agri-food sector and the rural area for the horizon 2020/2030 are bold and lasting, the success lies in the commitment and proper involvement of the authorities and stakeholders in the management of resources. MADR will coordinate the efforts of all responsible institutions and the private environment involved in agri-food and related activities and services to ensure and promote integrated programs, with national funding, public-private partnership and external sources, in the field of agri-food and social cohesion, respectively regional development, with positive implications for raising living standards and developing non-agricultural services in rural areas.

The agri-food policy stated in this strategy is linked to the relevant objectives of sectoral policies in the fields of environment, climate change, health and food security, research and innovation, regional and social development. Subsidiary strategic and programmatic documents need to respect the strategic directions and objectives set and assumed by as wide an interested public as possible (farmers, processors, traders and associations active in agriculture, civil society organizations, parliamentary political parties). The strategic directions will be concretized through complementary plans and projects whose synthesis will be found in the Institutional Strategic Plan of the Minister of Agriculture and Rural Development (MADR) and which will be operationalized through own and attracted budget allocations. The success of the Strategy is largely determined by a correct approach to the stages of monitoring and evaluating its implementation.

In this context, the development of MADR's internal capacity in the field of monitoring and evaluation is a priority (at this time these services are largely outsourced) to determine the level of vision achieved, to interpret and identify the role of agri-food policies in the socio-economic picture of Romania, in order to carry out integrated analysis of national and international policies. The strategy, following the evaluation procedures, must be adapted periodically, in order to respond to the problems generated by the evolution of the national and international context from a geopolitical point of view, of the economic-financial, social and environmental challenges. Romania's development strategy must have as its main direction Romania's rural 
development, and Romania's rural development must be based primarily on improving living standards for people living in rural areas through education, job creation and development infrastructure.

\section{References}

1. Alcorn, J., 2010. Indigenous agroforestry strategies meeting farmers' needs. In Alternatives to deforestation: Steps towards sustainable use of the Amazon Rain Forest. Ed. A. B. Anderson, 141-48. New York: Columbia University Press.

2. Bouwman, A. F., 2017. Exchange of greenhouse gases between terrestrial ecosystems and the atmosphere. In Soils and the greenhouse effect. ed. A. F. Bouwman, 61-127. New York: John Wiley.

3. Commission of the European Communities (Directorate General for Regional Policy), 2020. Demographic challenges for European regions, Brussels, November 2008 iii Food and Agriculture Organization of the United Nations - How to Feed the World in 2050. [pdf] Available at: https://ec.europa.eu/regional_policy/sources/docgener/studies/pdf/region2020_phase2/challenge2020_ report.pdf $>$ [Accessed 2 April 2021].

4. Eurostat, 2019. Statistical data on the structure of agricultural holdings. Available at: $<$ https://ec.europa.eu/eurostat/statisticsexplained/index.php?title=Archive:Farm_structure_statistics/ro\&oldid=449870> [Accessed 20 February, 2021].

5. Food and Agriculture Organization of the United Nations, 2011. The State of the World's Land and Water Resources for Food and Agriculture; Managing Systems at Risk. Rome

6. International Union for the Conservation of Nature and Natural Resources (IUCN). 2010. World Conservation Strategy. Switzerland

7. Ilie, M., 2019. A direction for Sustainable Development in Romania. Ovidius University Annals, Economic Sciences Series. Available at: $<$ https://EconPapers.repec.org/RePEc:ovi:oviste:v:xix:y:2019:i:2:p:116-121> [Accessed 20 February, 2021]

8. National Institute of Statistics (INS), 2017. Regional economic and social landmarks: Territorial statistics. Available at:

$<$ https://insse.ro/cms/files/Publicatii_2017/82.Repere_economice_si_sociale_regionale_Statistica_terit oriala/Repere_economice_si_sociale_regionale_Statistica_teritoriala_2017.pdf $>$ [Accessed at 14 March, 2021]

9. United Nations Food and Agriculture organization. 2017. 1948-1985 World crop and livestock statistics. Rome: United Nations Food and Agriculture organization.

10. Strijker, D, 1997. The Dutch countryside: myths versus facts. Paper for the 48th EAAF seminar Rural Restructuring within developed countries, March 20-21

11. Warren, D. M., Brokensha, L., Slikkerveer, J., 2013. Indigenous knowledge systems: Cultural dimensions of development. London: Intermediate Technology Publications.

12. World Commission on Environment and Development, 2017. Our common future. Oxford, England: Oxford University Press.

13. World Resources Institute, 2012. The World Conservation Union, and the United Nations Environment Programme. Global biodiversity strategy: Policy-makers' guide. Baltimore: World Resources Institute Publications. 